\title{
Early macronutrient intake and overweight at five years of age
}

\author{
S Scaglioni ${ }^{1 *}$, C Agostoni ${ }^{1}$, R De Notaris' ${ }^{1}$, G Radaelli $^{2}$, N Radice ${ }^{1}$, M Valenti ${ }^{1}$, M Giovannini ${ }^{1}$ and E Riva $^{1}$ \\ ${ }^{1}$ Department of Paediatrics, San Paolo Hospital, Milan, Italy; and ${ }^{2}$ Department of Informative Systems, University of Milan, Milan, Italy
}

OBJECTIVE: To examine the influence of the macronutrient intake in early life on the development of overweight in children.

DESIGN AND SUBJECTS: An ongoing longitudinal study including 147 randomized healthy children followed up from birth.

MEASUREMENTS: Anthropometric parameters were measured at birth, 1 and $5 \mathrm{y}$ of age. Dietary habits at the age of 1 and 5 were assessed by age-adjusted food-frequency questionnaires and $24 \mathrm{~h}$ recalls. Parents' body mass index (BMI) was also recorded.

RESULTS: Parental overweight was observed for $51 \%$ children. The prevalence of overweight at the age of $5 \mathrm{y}$ was higher in children with than without parental overweight $(37.3 \%$ vs $8.3 \%, P<0.0001)$. Five-year old overweight children had a higher percentage intake of proteins at the age of 1 y than non overweight children $(22 \%$ vs $20 \%$, $P=0.024)$ and lower intake of carbohydrates $(44 \%$ vs $47 \%, P=0.031)$. Multiple logistic analysis confirmed that protein intake at $1 \mathrm{y}$ of age was associated with overweight at 5 y $(P=0.05)$. In children born from overweight mothers, prevalence of overweight at the age of $5 \mathrm{y}$ tended to be higher in bottle-fed than in breast-fed ones $(62.5 \%$ vs $23.3 \%$, $P=0.08$ ).

CONCLUSION: Parental overweight is a major risk factor for childhood overweight in the first years of life, but an early high protein intake may also influence the development of adiposity.

International Journal of Obesity (2000) 24, 777-781

Keywords: macronutrient intake; body mass index; childhood obesity

\section{Introduction}

The widespread interest on the causes of childhood obesity is raised by its increasing prevalence in Western countries and the recognized association with adult obesity and related disorders. ${ }^{1-3}$ Preventive efforts have been aimed at identifying early markers influencing the development of obesity in children. ${ }^{4}$ In particular, high-fat and high-sugar, low-carbohydrate diets have been associated with the development of childhood adiposity, ${ }^{5}$ but the role of overeating is definitely unclear. ${ }^{6}$ Investigations assessing the role of energy and macronutrient (protein, fat, carbohydrate) intake in the development of adiposity in children have given controversial results. ${ }^{7-9}$ At the same time several reports have underlined the relevance of genetic factors in the development of childhood obesity. ${ }^{10-13}$ The distinction between genetic and environmental factors is difficult. Moreover, among environmental factors, it is relevant to distinguish between dietary habits when obesity is established and dietary habits before the onset of obesity, suggesting possible cause-effect relationships.

*Correspondence: S Scaglioni, Department of Paediatrics, San Paolo Hospital, 8 Via A. di Rudiní, I-20142 Milano, Italy.

E-mail: clinped@mailserver.unimi.it

Received 27 April 1999; revised 10 September 1999; accepted

6 January 2000
The aim of the present study was to examine the influences of the early intake of macronutrients on the development of overweight in healthy children.

\section{Subjects and methods}

Recruitment was made of 171 babies randomly selected ( 1 out of 4$)$ from all live births $(n=684)$ that occurred at our maternity ward during the second semester of 1991. Inclusion criteria were: weight at birth $\geq 2500$ g, gestational age 37-42 weeks inclusive, singleton birth, no neonatal disease or congenital malformation and Caucasian parents. Exclusion criteria were: at least one parent with debilitating infections, dysmetabolic and/or degenerative diseases, parental drug consumption. In all, 164 (95.9\%) infants (80 females, 84 males) satisfied the eligibility criteria and were included into this prospective study providing anthropometric and nutritional examinations at birth and age 1, 5, 8 and $12 \mathrm{y}$.

The trial was approved by the Institutional Ethical Committee. When infants entered their 9th month of age families were contacted. A pediatrician described the trial and informed consent was obtained from parents.

The analysis includes current information from the assessements at birth, 1 and $5 \mathrm{y}$ of age, when the growth parameters were measured and the dietary habits evaluated. When children were 1 y old, mothers 
were further interviewed about infants' feeding practice in the previous period, and both parents had weight and height measured.

Among breast-fed infants (84.3\%), mean (s.d.) of total duration of breastfeeding was 4.1 (3.6) months, while the mean (s.d.) duration of full (exclusive or predominant) breastfeeding was 2.7 (2.6) months. In the whole population the first solid foods were introduced between 4 and 6 months of age, according to the present dietary recommendations. ${ }^{14}$

Anthropometric measurements on children and parents were performed at our department by two experienced pediatricians according to a standardized procedure. In particular, for each anthropometric parameter three measurements were taken and the mean value was then considered for the analysis. The coefficient of variation of the measurements ranged from $0.7 \%$ to $1.3 \%$ (observer 1 ) and from $0.8 \%$ to $1.3 \%$ (observer 2 ). This comparable degree of interobserver measurement variation was deemed to yield reliable anthropometric data.

At birth and the age of $1 \mathrm{y}$, the body weight of the infants was measured by an electronic Sartorius scale accurate to $\pm 5 \mathrm{~g}$, and crown-heel length was measured on a portable measuring board to the nearest $0.1 \mathrm{~cm}$. At the age of $5 \mathrm{y}$ children had weight measured by an electronic scale accurate to $\pm 0.1 \mathrm{~kg}$ and height measured to the nearest $0.5 \mathrm{~cm}$ with a Harpenden stadiometer. The same procedure was used to evaluate parental anthropometry. Body mass index (BMI) was calculated from the ratio of weight to (height) ${ }^{2}$. A child was defined to be overweight if her/his BMI was over the 90th centile of the ageand sex-adjusted Rolland-Cachera curves. ${ }^{15}$ Parental BMI, evaluated when children were $1 \mathrm{y}$ old, was used in the statistical calculations. A parent was defined overweight if her $/ \mathrm{his}$ BMI $\left(\mathrm{kg} / \mathrm{m}^{2}\right)$ was greater than $25 .{ }^{16}$ Parental overweight occurred when at least one parent was overweight.

The dietary habits of children were determined by a well-trained and experienced dietitian on the basis of age-adjusted Food Frequency Questionnaires made up of 116 items and designed according to Block. ${ }^{17}$ The mothers were interviewed for approximately $50 \mathrm{~min}$ and each meal was analyzed to find out which food was eaten and how often. Usual portion sizes were estimated using household measures, the weight of purchase (eg pasta) or unit (eg fruit juice). A $24 \mathrm{~h}$ recall was further conducted at the end of the interview to standardize the usual serving size. Quantification and analysis of the energy intake and nutrient composition were performed with an ad hoc PC software program developed at our department and based on the Food and Nutrient Data Base issued by the National Institute of Nutrition. ${ }^{18}$ The sample size had been determined assuming in our area an expected prevalence of overweight (defined according to the Rolland-Cachera curves) ${ }^{15}$ in 5-6y-old children of $12.5 \%,{ }^{19}$ in order to include at age $5 \mathrm{y}$ at least 20 overweight children.

\section{Statistical analysis}

Descriptive results are given as mean (s.d.) or percentage. The odds ratio (OR) and 95\% confidence interval (CI) were calculated when appropriate. Student's $t$ test and the non-parametric Wilcoxon and Mann-Whitney tests were used to compare between-groups differences of continuous variables. The chi-square test and the Fisher's exact test were used to compare discrete variables. Multiple logistic analysis was carried out to estimate the independent contribution of macronutrient intake at the age of $1 \mathrm{y}$ on overweight at the age of $5 \mathrm{y}$. Factors associated with a $P<0.05$ at univariate analysis were analyzed by multiple logistic regression and adjusted on potential confounding variables (infant's gender, weight and length at birth and $1 \mathrm{y}$ of age, parental age). All values of $P$ less than 0.05 were considered to indicate statistical significance (two-tailed test). The SPSS package version 7.5 for Windows (SPSS Inc., Chicago, IL, USA) was used for the statistical analysis.

\section{Results}

Follow-up data at the age of $5 \mathrm{y}$ were available in 147 $(89.6 \%)$ children, 67 females and 80 males. Figure 1 indicates the longitudinal changes in BMI of children during the examination period. The prevalence of overweight increased from $10.9 \%$ at $1 \mathrm{y}$ of age to $23.1 \%$ at $5 \mathrm{y}(P<0.001)$. There was no significant difference in the prevalence between boys and girls, both at the age of $1 \mathrm{y}(8.7 \% v s 13 \%, P=0.62)$ and $5 \mathrm{y}$ $(20.0 \%$ vs $26.9 \%, P=0.32)$. Parents' age was not associated with the overweight in children at any time (minimum $P=0.44$ ).

Tables 1 and 2 show the relationship of overweight at the age of $5 \mathrm{y}$ to anthropometric parameters and the dietary intake at the age of $1 \mathrm{y}$, respectively.

No significant correlation was found between the children's BMI at the age of $1 \mathrm{y}$ and parental BMI

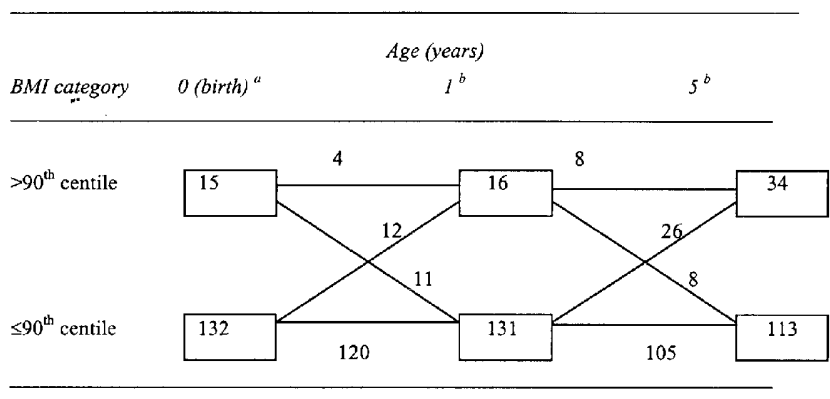

Figure 1 Longitudinal variation in BMI of children. Horizontal lines: no change in BMI category between age groups; ascending lines: BMI category increased; descending lines: BMI category decreased. Numbers indicate the number of children. Difference statistically significant from 1 to 5 years of age $\left(P<0.001\right.$, Wilcoxon matched pairs signed-ranks test). ${ }^{\text {aS Sex- }}$ adjusted 90th centile calculated from the sample (females $15.4 \mathrm{~kg} / \mathrm{m}^{2}$, males $15.8 \mathrm{~kg} / \mathrm{m}^{2}$ ); ${ }^{\mathrm{b}} \mathrm{Age}$ - and sex-adjusted 90th centile according to curves from Rolland-Cachera et al. ${ }^{15}$ 
(minimum $P=0.10$ ). Children's BMI at $5 \mathrm{y}$ of age positively correlated with BMI at $1 \mathrm{y} \quad(r=0.46$, $P<0.0001)$, father's BMI $(r=0.35, P<0.0001)$ and mother's BMI ( $r=0.21, P=0.01)$. Overweight at $5 \mathrm{y}$ was more likely in children with $(n=75)$ than without $(n=72)$ parental overweight $(37.3 \%$ vs $8.3 \%$; $\mathrm{OR}=6.55,95 \% \mathrm{CI}=2.51-17.10)$. It appears from Table 2 that children overweight at $5 \mathrm{y}$ ingested at $1 \mathrm{y}$ a significantly higher percentage of energy as proteins and a lower percentage as carbohydrates than nonoverweight children. Fat intake was comparable and slightly lower than $35 \%$ in both groups.

At the age of $5 \mathrm{y}$ no significant difference was found between overweight and non-overweight children for any dietary nutrient (Table 3 ). In both groups, there was a significant drastic reduction of the protein intake from 1 to $5 \mathrm{y}$ of age $(P<0.0001)$ and an increase of the carbohydrate intake $(P<0.0001)$. Significance of the reduction of the fat intake was less marked $(P=0.01$ in non-overweight children, $P=0.06$ in overweight children). Moreover, in non-

Table 1 Comparison of anthropometric parameters of infants at birth and $1 \mathrm{y}$, and parents, as a function of children's BMI at the age of $5 y$. Values are mean (s.d.)

\begin{tabular}{|c|c|c|c|}
\hline \multirow[b]{2}{*}{ Characteristic } & \multicolumn{2}{|c|}{$B M I$ at age $5 y$} & \multirow[b]{2}{*}{$P$} \\
\hline & $\begin{array}{c}\leq 90 \text { th centile } \\
\quad(n=113)\end{array}$ & $\begin{array}{c}>90 \text { th centile } \\
\quad(n=34)\end{array}$ & \\
\hline Infant birth weight $(\mathrm{g})$ & $3274(460)$ & $3451(508)$ & 0.053 \\
\hline birth length $(\mathrm{cm})$ & $49.2(1.0)$ & $49.5(1.3)$ & 0.185 \\
\hline birth BMI $\left(\mathrm{kg} / \mathrm{m}^{2}\right)$ & $13.4(1.4)$ & $14(1.6)$ & 0.051 \\
\hline Infant weight at 1 y $(\mathrm{kg})$ & $9.7(1.0)$ & $10.5(1.0)$ & $<0.0001^{*}$ \\
\hline height at $1 \mathrm{y}(\mathrm{cm})$ & $77.8(2.7)$ & $76.7(3.0)$ & 0.843 \\
\hline BMI at $1 \mathrm{y}\left(\mathrm{kg} / \mathrm{m}^{2}\right)$ & $16.5(1.5)$ & $17.8(1.4)$ & $<0.0001^{*}$ \\
\hline Maternal weight $(\mathrm{kg})$ & $59.6(8.9)$ & $65.7(14.7)$ & $0.020 *$ \\
\hline height $(\mathrm{cm})$ & $159(21)$ & $157(27)$ & 0.745 \\
\hline BMI $\left(\mathrm{kg} / \mathrm{m}^{2}\right)$ & $22.9(3.5)$ & $25.1(5.4)$ & $0.032 *$ \\
\hline Paternal weight $(\mathrm{kg})$ & $74.4(9.3)$ & $79.2(10.3)$ & $0.008^{*}$ \\
\hline height $(\mathrm{cm})$ & $168(32)$ & $175(8)$ & 0.218 \\
\hline BMI $\left(\mathrm{kg} / \mathrm{m}^{2}\right)$ & $24.5(2.5)$ & $26.5(3.0)$ & $<0.0001^{*}$ \\
\hline Midparental BMI & $23.7(2.5)$ & $25.8(2.9)$ & $<0.0001^{*}$ \\
\hline
\end{tabular}

* = statistical significance.

Table 2 Comparison of energy and nutrient intake in children at the age of $1 \mathrm{y}$, as a function of children's BMl at the age of $5 \mathrm{y}$. Values are mean (s.d.)

\begin{tabular}{|c|c|c|c|}
\hline \multirow[b]{2}{*}{ Characteristic } & \multicolumn{2}{|c|}{$B M I$ at age $5 y$} & \multirow[b]{2}{*}{$P$} \\
\hline & $\begin{array}{c}\leq 90 \text { th centile } \\
\quad(n=113)\end{array}$ & $\begin{array}{c}>90 \text { th centile } \\
\quad(n=34)\end{array}$ & \\
\hline \multicolumn{4}{|l|}{ Daily energy } \\
\hline total $(\mathrm{kJ})$ & 3545.5 (1201) & $3440.9(1000)$ & 0.663 \\
\hline (kcal) & $847(287)$ & $822(239)$ & 0.663 \\
\hline per kg body weight $(\mathrm{kJ} / \mathrm{kg})$ & $364.2(125.6)$ & $330.7(96.3)$ & 0.149 \\
\hline$(\mathrm{kcal} / \mathrm{kg})$ & $87(30)$ & $79(23)$ & 0.149 \\
\hline \multicolumn{4}{|l|}{ Nutrient (energy \%) } \\
\hline proteins & $20(3)$ & $22(5)$ & $0.024^{*}$ \\
\hline carbohydrates & $47(7)$ & $44(8)$ & $0.031 *$ \\
\hline fats: & $33(5)$ & $34(4)$ & 0.728 \\
\hline saturated & $15(3)$ & $15(3)$ & 0.788 \\
\hline monounsaturated & $10(2)$ & $11(2)$ & 0.161 \\
\hline polyunsaturated & $6(1)$ & $6(1)$ & 0.595 \\
\hline
\end{tabular}

* = statistical significance. overweight children a significant correlation was found between intakes of carbohydrates $(r=0.23$, $P=0.02)$ and fats $(r=0.19, P=0.05)$ as percentages of energy at 1 and $5 \mathrm{y}$ of age.

Table 4 shows the relationship between parental overweight and the dietary intakes of children at the age of $1 \mathrm{y}$. No statistically significant association was found.

The multiple logistic regression identified parental BMI as the most relevant factor associated with overweight at $5 \mathrm{y}$ of age (father's BMI, $P=0.003$; mother's BMI, $P=0.05)$. Among macronutrients, only protein intake as a percentage of energy at $1 \mathrm{y}$ was associated with overweight at $5 \mathrm{y} \quad(P=0.05)$. Similar results were obtained when parental overweight instead of parental BMI entered the logistic model (parental overweight, $P=0.0002$; protein percentage, $P=0.07)$.

Another logistic analysis was performed on the subsample of 131 children who were not overweight at the age of $1 \mathrm{y}$. In this group the adjusted association of the

Table 3 Comparison of energy and nutrient intake in children at the age of $5 y$, as a function of children's BMI at the age of $5 y$. Values are mean (s.d.)

\begin{tabular}{|c|c|c|c|}
\hline \multirow[b]{2}{*}{ Characteristic } & \multicolumn{2}{|c|}{$B M I$ at age $5 y$} & \multirow[b]{2}{*}{$P$} \\
\hline & $\begin{array}{c}\leq 90 \text { th centile } \\
\quad(n=113)\end{array}$ & $\begin{array}{c}\text { 90th centile } \\
\quad(n=34)\end{array}$ & \\
\hline \multicolumn{4}{|l|}{ Daily energy } \\
\hline total $(\mathrm{kJ})$ & 9193.0 (2067) & $9676.4(2519)$ & 0.077 \\
\hline (kcal) & $2196(494)$ & $2312(602)$ & 0.077 \\
\hline \multicolumn{4}{|l|}{ per kg body weight } \\
\hline$(\mathrm{kJ} / \mathrm{kg})$ & 489.6 (104.6) & $431.0(113.0)$ & 0.218 \\
\hline (kcal/kg) & $117(25)$ & $103(27)$ & 0.218 \\
\hline \multicolumn{4}{|l|}{ Nutrient (energy \%) } \\
\hline proteins & $15(2)$ & $15(2)$ & 0.530 \\
\hline carbohydrates & $53(5)$ & $53(4)$ & 0.218 \\
\hline fats: & $32(4)$ & $32(4)$ & 0.917 \\
\hline saturated & $12(2)$ & $12(2)$ & 0.907 \\
\hline monounsaturated & $11(1)$ & $12(1)$ & 0.401 \\
\hline polyunsaturated & $4(1)$ & $4(1)$ & 0.529 \\
\hline
\end{tabular}

* = statistical significance.

Table 4 Comparison of energy and nutrient intake at the age of $1 \mathrm{y}$, as a function of parental overweight. Values are mean (s.d.)

\begin{tabular}{lccc}
\hline & \multicolumn{2}{c}{ Parental overweight } \\
\cline { 2 - 3 } & \multicolumn{2}{c}{ Yes } & No \\
Characteristic & $(n=75)$ & $(n=72)$ & $P$ \\
\hline Daily energy & & & \\
total (kJ) & & & \\
$\quad(\mathrm{kcal})$ & $3516.2(1146.9)$ & $3524.6(1167.8)$ & 0.955 \\
Per kg body weight & $840(274)$ & $842(279)$ & 0.955 \\
$\quad(\mathrm{~kJ} / \mathrm{kg})$ & $364.2(117.2)$ & $351.6(125.5)$ & 0.490 \\
$\quad(\mathrm{kcal} / \mathrm{kg})$ & $87(28)$ & $84(30)$ & 0.490 \\
Nutrient (energy \%) & & & \\
proteins & $20(4)$ & $21(4)$ & 0.479 \\
carbohydrates & $47(8)$ & $46(7)$ & 0.487 \\
fats: & $33(5)$ & $33(5)$ & 0.622 \\
$\quad$ saturated & $15(3)$ & $15(3)$ & 0.571 \\
$\quad$ monounsaturated & $10(2)$ & $10(2)$ & 0.945 \\
$\quad$ polyunsaturated & $6(1)$ & $6(1)$ & 0.648 \\
\hline
\end{tabular}


protein intake as a percentage of energy at $1 \mathrm{y}$ with overweight at $5 \mathrm{y}$ was more marked (parental overweight, $P=0.0004$; percentage protein, $P=0.03$ ).

Finally, an analysis was carried out to assess whether the type of feeding at birth might be associated with overweight at the age of $5 \mathrm{y}$. When the sample was analyzed as a whole, overweight at $5 \mathrm{y}$ of age occurred in $21.8 \%$ of 124 breast-fed children, and in $30.4 \%$ of 23 bottle-fed children $(P=0.52)$. The difference was remarkably greater in the group of 38 children born from overweight mothers $(23.3 \%$ vs $62.5 \%)$ and approached statistical significance $(P=0.08)$. In this group the risk of being overweight at $5 \mathrm{y}$ of age for bottle-fed children $(n=8)$, when compared to breast-fed children $(n=30)$, was 2.68 . Among the breast-fed children, duration of full breastfeeding (mean \pm s.d.) tended to be longer in children who were not overweight at $5 \mathrm{y}(2.9 \pm 2.6$ months $)$ than in overweight ones ( $2.2 \pm 2.7$ months), although the difference was not significant $(P=0.358)$. In breast-fed children overweight at $5 \mathrm{y}$ and born from overweight mothers, duration of full breast-feeding was even shorter (1.4 \pm 1.8 months).

\section{Discussion}

Dietz has stated that 'Although obesity-associated morbidities occur more frequently in adults, significant consequences of obesity as well as the antecedents of adult disease occur in obese children and adolescents'. ${ }^{20}$ To design effective preventive interventions any possible relationship between genetic and environmental factors should be investigated. Few prospective studies have examined the mutual role of environmental and genetic factors on childhood obesity. ${ }^{21,22}$ Dietary habits may be the most relevant environmental factor possibly influencing the early development of obesity. In particular, interest has been focused on the dietary habits during the early periods of life, including the milk-feeding period and the transition from the milk to an omnivorous diet. $^{23}$

In the present prospective study we have investigated the association of overweight at $5 \mathrm{y}$ of age with macronutrient intake at $1 \mathrm{y}$ and parental overweight.

It may be pointed out that in our sample prevalence of parental overweight was very high (51\%). Although the reasons for this high value are open to speculation, the present findings are consistent with previous results. ${ }^{24,25}$ Indeed, the Italian Household Multipurpose Survey ${ }^{24}$ estimated in the general adult population an overall prevalence of overweight $(\mathrm{BMI} \geq 25)$ of $31.6 \%$, and in particular a value of $44.7 \%$ and $54.5 \%$ in middle-aged women and men, respectively.

Prevalence of overweight in children was $10.9 \%$ at the age of $1 \mathrm{y}$ and increased to $23.1 \%$ at $5 \mathrm{y}$. The quite high prevalence at $5 \mathrm{y}$ of age may be partially explained on the basis of the high prevalence of parental overweight and the high protein intake at the age of $1 \mathrm{y}$. Indeed, in agreement with the literature, ${ }^{26}$ we have found a strong association between children's and parental overweight. Moreover, the average protein intake at $1 \mathrm{y}$ was about $20 \%$ of the energy intake, a value similar to that found in a previous study performed in our area, ${ }^{27}$ but remarkably higher than the $10-12 \%$ level indicated by the Italian Recommended Dietary Allowances ${ }^{28}$ and also than the median value of $15 \%$ estimated in the Copenhagen Cohort study. ${ }^{29}$

Such a high protein intake at $1 \mathrm{y}$ might be surprising and needs further investigation. Therefore some caution has to be paid in extending conclusions to other general populations. However, the role of the early protein intake in the development of later obesity may be further emphasized by our observations on infants not overweight at $1 \mathrm{y}$ of age and is also supported by other authors. ${ }^{30}$ Rolland-Cachera and colleagues found that protein intake at the age of $2 \mathrm{y}$ is associated with the pattern of fatness development at $8 \mathrm{y}$. They hypothesized that a high protein intake could trigger adipocyte multiplication (normally starting at $8 \mathrm{y}$, but starting at an even earlier age in the obese ${ }^{31}$ ) by stimulating the production of insulin-like growth factors. ${ }^{32}$ Based on early experience, Rolland-Cachera proposed another interesting model using GH and IGF1 concentration to explain adiposity variation. ${ }^{33}$

Our data also suggest a positive role of breastfeeding in the prevention of the development of overweight, especially in infants born to overweight mothers. This hypothesis is supported by a recent cross-sectional study performed among children aged 5-6y. ${ }^{34}$ The authors of this survey have found that breast-feeding had a significant protective role in preventing early obesity development. Furthermore, the Darling Study suggested that the low protein content of human milk, as compared to formula, may account for breast-fed infants being thinner than bottle-fed infants in the first $2 y$ of life..$^{35}$

The dietary pattern of children may be influenced by child-feeding practices too. It has been suggested that eating environments may differ between families with and without overweight parents. ${ }^{36}$ Our data did not highlight significant associations of parental overweight with any macronutrient intake at the age of $1 \mathrm{y}$.

More longitudinal studies are needed to clarify the independent role of the genetic background and the early dietary patterns on the development of overweight in childhood. Anyway, the high rate of overweight at the age of $5 \mathrm{y}$, besides confirming the increasing prevalence of overweight in Western areas,${ }^{37}$ also emphasizes the need to promote effective preventive programs.

\section{References}

1 Nieto FJ, Szklo M, Comstock GW. Childhood weight and growth rate as predictors of adult mortality. Am J Epidemiol 1992; 136: 201-213. 
22 Must A, Jacques PF, Dallai GE, Bajema CJ, Dietz WH. Long-term morbidity and mortality of overweight adolescents: a follow up of the Harvard Growth Study of 1922 to 1935. $N$ Engl J Med 1992; 327: 1350-1355.

3 Bao W, Srinivasan SR, Wattingney WA, Berenson GS. Persistence of multiple cardiovascular risk clustering related to Syndrome X from childhood to young adulthood. Arch Intern Med 1994; 154: 1842-1847.

4 Rosenbaum M, Leibel RL. The physiology of body weight regulation: Relevance to the etiology of obesity in children. Pediatrics 1998; 101: 525-539.

5 Birch LL, Fisher JO. Development of eating behaviors among children and adolescents. Pediatrics 1998; 101: 539-549.

6 Rolland-Cachera MF, Bellisle F, Tiche J, Chantrel AM, Guilloud Bataille M,Vol S, Pequignot G. Relationship between adiposity and food intake: an example of pseudo-contradictory results obtained in case-control versus between- population studies. Int J Epidemiol 1990; 19: 571-577.

7 Frank GC, Berenson GS, Webber LS. Dietary studies and the relationship of diet to cardiovascular disease risk factor variables in 10-year-old children: the Bogalusa heart study. Am J Clin Nutr 1978; 31: 328-340.

8 Rolland-Cachera MF, Bellisle F. No correlation between adiposity and food intake: why are working class children fatter? Am J Clin Nutr 1986; 44: 779-787.

9 Rossner S. Mycket protein till barn okar risken for overvikt. (High protein intake in children increases the risk of obesity.) Lakartidningen 1995; 92 : 4182.

10 Rosenbaum M, Leibel R. Pathophysiology of childhood obesity. $A d v$ Pediatr 1988; 35: 73-137

11 Stunkard A, Foch T, Hrubec Z. A twin study of human obesity. JAMA 1986; 256: 51-54.

12 Stunkard A, Sorensen T, Hanis C, Teasdale TW, Chakraborty R, Schull WJ, Schulsinger F. An adoption study of human obesity. N Engl J Med 1986; 314: 193-198.

13 Bouchard C. Current understanding of the etiology of obesity: genetic and nongenetic factors. Am J Clin Nutr 1991; 53: 1561S-1565S.

14 ESPGAN, Committee on nutrition, Acta Paediatr Scand 1981; (suppl) 287.

15 Rolland-Cachera MF, Sampè M, Guilloud-Bataille M, Patois E, Pequinot- Gugenbuhl F, Fautrad V. Adiposity indices in children. Am J Clin Nutr 1982; 36: 178-184.

16 Pi-Sunyer FX. Obesity. In Shils ME, Young VR, eds. Modern nutrition in health and disease, 7th edn Lea \&Febiger: Philadelphia, 1988, pp 795-816.

17 Block G, Hartman AM, Dresser CM, Carroll MD, Gannon J, Gardner L. A data-based approach to diet questionnaire design and testing. Am J Epidemiol 1986; 124: 453-469.

18 Istituto Nazionale della Nutrizione (Italian Institute of Nutrition). Food composition tables. Rome, 1986.

19 Giovannini M, Galluzzo C, Scaglioni S, Ortisi MT, Rottoli A, Longhi R, Riva E, Zuccotti G, Garofalo R, Bellù R, Consalez $\mathrm{G}$, Agostoni C. Indagine nutrizionale nel Comune di Milano: dati antropometrici, intake calorici e abitudini alimentari in età scolare. (Anthropometric data and dietary habits of a pediatric population in Milan.) Riv Ital Ped (I J P) 1986; 12: 533-540.
20 Dietz WH. Health consequence of obesity in youth: childhood predictors of adult disease. Pediatrics 1998; 101: 518-525.

21 Klesges RC, Klesges LM, Eck LH, Shelton ML. A longitudinal analysis of accelerated weight gain in preschool children. Pediatrics 1995; 95: 126-132.

22 Bouchard C, Leon A, Rao D, Skinner J, Wilmore J, Gagnon J. The heritage family study. Aims, designs and measurement protocol. Med Sci Sports Exerc 1995; 27: 721-729.

23 Barker DJ, Osmond C, Winter PD, Simmonds SJ, Margetts B. Weight in infancy and death from ischemic heart disease. Lancet 1989; 2: (8663): 577-580.

24 Pagano R, La Vecchia C. Overweight and obesity in Italy, 1990-91. Int J Obes Relat Metab Disord 1994; 18: 665-669.

25 Lupo A. Nutrition in general practice in Italy. Am J Clin Nutr 1997; 65(Suppl): 1963S-1066S.

26 Whitaker RC, Wright JA, Pepe MS, Seidel KD, Dietz WH. Predicting obesity in young adulthood from childhood and parental obesity. N Engl J Med 1997; 337: 869-873.

27 Bellù R, Ortisi MT, Incerti P, Mazzoleni V, Martinoli G, Agostoni C, Galluzzo C, Riva E, Giovannini M. Nutritional survey on a sample of one-year-old infants in Milan: intake of macronutrients. Nutr Res 1991; 11: 1221-1229.

28 Società Italiana di Nutrizione Umana (Italian Society of Human Nutrition). In Livelli di assunzione giornalieri raccomandati di energia e nutrienti per la popolazione italiana. (Italian Recommended Daily Allowances). Rome, 1996, pp $49-61$.

29 Michaelsen KF. Nutrition and growth during infancy. The Copenhagen Cohort Study. Acta Paediatr 1997; 420(Suppl): 16.

30 Rolland-Cachera MF, Deheeger M, Akrout M, Bellisle F. Influence of macronutrients on adiposity development: a follow up study of nutrition and growth from 10 months to 8 years of age. Int J Obes Relat Metab Disord 1995; 19: 573-578.

31 Knittle JL, Timmers K, Ginsberg-Fellner F, Brown RE, Katz DP. The growth of adipose tissue in children and adolescents. Cross-sectional and longitudinal studies of adipose cell number and size. J Clin Invest 1979; 63: 239-246.

32 Clemmons DR, Underwood LE. Nutritional regulation of IGFI and IGF binding proteins. An Rev Nutr 1991; 11: 393-412.

33 Rolland-Cachera MF, Deheeger M, Bellisle F. Early nutrition and later outcomes. 6th European Congress on Obesity, Copenhagen, 31 May-3 June, 1995.

34 Von Kries R, Koletzko B, Sauerwald T, Von Mutius E, Barnert D, Grunert V, Von Voss H. Breastfeeding and obesity: cross sectionsl study. Br Med $J$ 1999; 319: 147-150.

35 Dewey KG, Heinig J, Nommsen LA, Peerson JM, Lonnerdal B. Growth of breast-fed and formula-fed infants from 0 to 18 months: the Darling Study. Pediatrics 1992; 89: 1035-1041.

36 Oliveria SA, Ellison RC, Moore LL, Gillman MW, Garrahie EJ, Singer MR. Parent-child relationships in nutrient intake: the Framingham children's study. Am J Clin Nutr 1992; 56: 593-598.

37 Troiano RP, Flegal KM. Overweight children and adolescents: description, epidemiology and demographics. Pediatrics 1998; 101: $497-504$. 